\section{Lettlest om barn og søvn}

Heier MS, Wolland AM

Barn og søvn

128 s, ill. Oslo: Cappelen Damm, 2009

Pris NOK 248

ISBN 978-82-02-306472

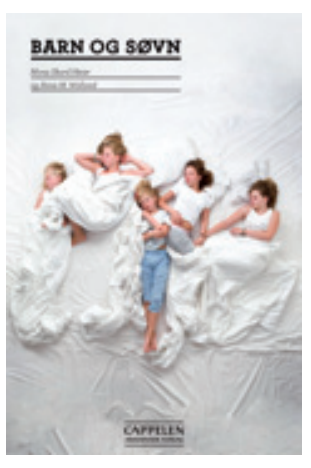

Forfatterne henvender seg først og fremst til voksne som har barn med søvnrelaterte problemer eller som har generell interesse for barn og søvn. De definerer ikke selv målgruppen nærmere. Det hele innledes av to små kapitler - en kort innføring i hva som er normal søvn og et om forandring av søvnen med alderen. Deretter kommer hoveddelen, som omhandler ulike sider av søvn og søvnvansker hos barn og ungdom. Det er ett kapittel som omhandler søvnundersøkelser og ett som er bygd opp med spørsmål og svar knyttet til barn og ungdom og søvn. I siste del er det en ordliste med faguttrykk.

Språket er enkelt, og faguttrykkene forklares i stor grad fortløpende. Det gjør at man ikke trenger forhåndskunnskap for å ha glede av denne utgivelsen. Sentrale begreper står i venstre marg. Det er et grep som gir god oversikt og gjør det lett å finne frem. Tekstrammer med gode oppsummeringer er et fint supplement. De fleste søvnvanskene presenteres først med en generell beskrivelse. Deretter er det et avsnitt med årsak, og til sist kommer relevante forslag til behandling. Behandlingsforslagene er stort sett praktiske og konkrete. En del av disse gjentas i mer «muntlig» form som svar på spørsmål i eget kapittel bakerst.

De innledende kapitlene om normal søvn og utvikling er godt skrevet om et til dels vanskelig og komplekst tema. Kapitlene som omhandler søvnproblemer er dels ordnet etter alder (Søvnvansker hos barn/ Større barn og ungdom), dels etter dominerende symptomer (Søvngjengeri og annen uro i søvne/Det trette barnet). Dette kan virke litt uryddig når man skal finne frem. Forfatterne behandler viktige søvnsykdommer som f.eks. søvnapnésyndrom og narkolepsi på en grundig og bred måte. Jeg synes de klarer å balansere det generelle perspektivet og «barneperspektivet» på en god måte. Enkelte temaer, som for eksempel hodedunking, behandles noe ioverkant summerisk. Kapitlet om hvordan søvnen undersøkes er kortfattet, men grundig. Man kan merke at forfatterne har spesielt god kjennskap til det diagnostiske feltet. Det er en omfattende litteraturliste. Aktuelle lærebøker om emnet kunne med fordel ha vært skilt ut $\mathrm{i}$ en egen liste.
Barn og søvn er lettlest og kortfattet og velegnet som oppslagsbok for voksne som har barn med søvnproblemer eller generell interesse for barns søvn. Den kan også fungere som en innføring i emnet for interessert helsepersonell.

\section{Eyvind Rugland}

Seksjon for klinisk nevrofysiologi

Nevroklinikken

Akershus universitetssykehus

\section{Etter ulykken}

Lundälv J

\section{Stöd efter krasch}

96 s, ill. Gävle: Meyers, 2009. Pris SEK 169 ISBN 978-91-7111-142-5

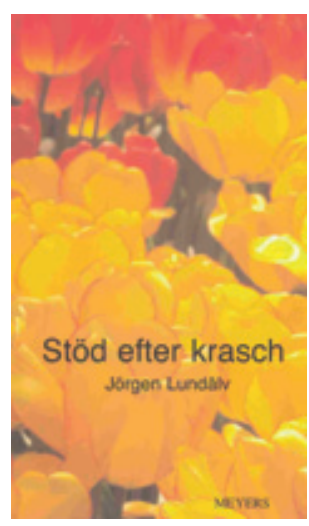

Forfatteren henvender seg i første rekke til de trafikk skadede og deres pårørende, men her er også mye informasjon som kan nyttes av andre som blir involvert i forbindelse med personskader etter trafikkulykker. Han omtaler spesifikt helsevesen, lovverk, samar-

beidslinjer og instanser i Sverige. Selv om forholdene i Sverige og Norge er godt sammenliknbare, er det en rekke av de omtalte realiteter som er av begrenset interesse for norske lesere.

I forordet beskriver Lundälv sin egen rolle, som primært var journalistens på et skadested. Han fattet så sterk interesse for dette temaet at han ble forsker. Det redegjøres ikke nærmere for på hvilket nivå han har drevet sin forskning. Han gir imidlertid en god begrunnelse for hvorfor det er nyttig med en utgivelse som denne. Mange skadede og deres pårørende er i villrede om hva de kan og skal gjøre etter ulykken. Stöd efter krasch har således sin berettigelse som et enkelt oppslagsverk for dette formål. Forfatterens forord etterfølges av forord fra representanter for to ulike grupper pasienter, dette for å vektlegge utgivelsens betydning ytterligere.

Det er en rekke forkortelser, som er forklart på side15. På tross av dette er det lett å gå seg vill. Det er nødvendig stadig å slå tilbake til dette registeret for få med seg hva som omtales.

Den store underrapporteringen av antallet trafikkskadede omtales og

beskrives som et problem. Dette er et verdifullt innspill, idet man ser samme underrapportering også i mange andre land. Trafikkskadeproblemet blir ofte kun oppfattet som et akuttbehandlingsproblem. De mindre synlige akuttskadene og de mange langvarige skadefølgene blir mindre estimert. Forfatteren skriver om «de dolda skador», som han mener krever mer oppmerksomhet i form av tilbud om oppfølging enn det pasientene får.

I de etterfølgende kapitler beskrives de ulike støtteordningene som finnes i Sverige, det er en beskrivelse av opplevelsen som nyskadet, ulike forsikringsordninger og fremtidsutsikter. Etter denne delen følger en sparsom og summarisk omtale av et lite utvalg skadegrupper. Dette kapitlet burde være satt inn før den første omtalen av støtteordningene. Etter beskrivelsen av enkelte skadegrupper kommer en ny omtale av støtteformer. Denne hoppingen frem og tilbake virker noe uryddig. Et viktig moment som trekkes frem i dette kapitlet er vektleggingen av individuell plan for den enkelte. Her kan mange med ansvar for både skadede og andre pasienter ha noe å lære.

Kapitlet om de pårørendes rolle er kort, men bra. Her gjøres det oppmerksom på hva de bør få vite, hva de må få vite og hva de kan bidra med. I det etterfølgende kapitlet omtales den støtte det kan ligge $i$ at de skadede kan lære av hverandre.

Mediene gis omtale som nyhetsformidlere, noe som kan være belastende for pasienten. Det legges også vekt på den positive rolle mediene har ved å formidle informasjon som kan bidra til å styrke det ulykkesforebyggende og skadereduserende arbeidet.

Sorgprosessen for de overlevende skadede med skadefølger og for de pårørende ved tap av liv gis en god og verdig omtale. Forfatteren tar også for seg praktiske problemer som kan oppstå ved ulykke i fremmed land, og kommer med konkrete råd for at man skal stå best mulig rustet til en slik situasjon.

Fagdelen av boken etterfølges av noen dikt skrevet av skadede. Mange av disse gir grunn til ettertanke.

Det er ingen regulære litteraturreferanser, men en omfattende oversikt over bøker som kan gi mer kunnskap.

I siste del er det en fyldig opplisting av sentrale begreper i skadesammenheng og om svensk lovgivning. Dessuten er det en liste over viktige adresser samt artikler som kan gi nyttig informasjon og mer innsikt.

Stöd efter krasch gir samlet sett nyttig generell kunnskap for de trafikkskadede selv og for de mange som er involvert som pårørende, behandlere og saksbehandlere. Den sterke vektleggingen av svenske forhold og institusjoner gjør at den er mindre nyttig i Norge enn i vårt naboland i øst.

\section{Inggard Lereim}

Institutt for nevromedisin

Norges teknisk-naturvitenskapelige universitet 